\title{
Assessment of Arctic and Antarctic Sea Ice Condition Differences in the Scope of the Polar Code
}

\author{
(1) Meriç Karahalil ${ }^{1}$, () Burcu Özsoy ${ }^{1,2}$ \\ ${ }^{1}$ Istanbul Technical University, Department of Maritime Transportation Engineering, Istanbul, Turkey \\ ${ }^{2}$ Scientific and Technological Research Council of Turkey (TUBITAK MAM), Polar Research Institute (KARE), Istanbul, Turkey
}

\begin{abstract}
Polar regions face increasing challenges resulting from the interactions between global climate change, human activities, and economic and political pressures. As the sea ice extent trends diminish, maritime operations have started increasing in these regions. In this respect, an international concern has arisen for the shrinking of sea ice, preserving the environment, and passengers' and seafarers' safety. The International Maritime Organization has enforced the Polar Code (PC) for the ships navigating in these challenging Arctic and Antarctic waters. Polar regions are similar in some aspects but exhibit significant differences in geographical conditions, maritime activities, and legal status. Therefore, the PC that applies to both regions should be reconsidered, accounting for the differences between the areas for further development. This study considers the Arctic and Antarctic geographical differences relevant to the PC's scope. The emphasis is placed on the changes regarding the sea ice extent and sea ice condition differences in the two regions, which are essential in maritime safety. This study also addresses the aspects of the PC that need improvement.
\end{abstract}

Keywords

Polar regions, Sea ice change, Maritime activities, Polar Code, Maritime safety

\section{Introduction}

The Arctic and Antarctic regions are the coldest places on the planet. Nevertheless, their environments are shaped by different forces. The Arctic region consists of a partly ice-covered ocean surrounded by the land areas of the eight Arctic countries. It is most commonly defined as the region above the $66^{\circ} 33^{\prime} \mathrm{N}$ latitude parallel $[1,2]$. On the other hand, the Antarctic is a frozen land encompassed by the Southern Ocean, which is situated south of the $60^{\circ} \mathrm{S}$ latitude parallel [3]. There are notable variances between them. For instance, the Antarctic sea ice forms a symmetric circle around the south pole, whereas the Arctic sea ice is asymmetric through some longitudes as a result of the effects of the ocean currents and winds [4,5]. The Arctic sea ice is not as mobile as that of the Antarctic and is sometimes stationary for more than five years. On the other hand, the Antarctica sea ice does not stay on for ages or thicken as much as that in the Northern hemisphere $[5,6]$. Thus, the sea ice thickness and volume vary notably within both regions. The Antarctic sea ice is characteristically one to two meters thick, while a large part of the Arctic is two to three meters thick.

Although geographical and seasonal differences exist, both the Arctic and Antarctic are especially susceptible to the impacts of global climate change with the reduction of the sea ice volume and extent [7-11]. The primary cause for the decline is the increase in global mean temperatures linked to climate change. A large amount of ice loss in summer has been accelerated by warmer air temperatures that have resulted in a delay in the freezing of polar waters [12]. Some studies reveal that the Northern Hemisphere may become ice-free in summers soon $[11,13,14]$. On the other hand, increases in the Antarctic annual average sea ice coverage reached their highest record in 2014 according to the 19792018 satellite passive microwave records. However, this was followed by a sharp decline leading to the lowest value being 
measured in 2017 [15]. Notably, sea ice prediction models and studies indicate that the Arctic sea ice extent (SIE) has been decreasing at an alarming percentage since 1990, whereas the Antarctic region trends have been different.

The melting rates explained above create less sea ice, presenting maritime opportunities, particularly in the Arctic [16]. Potential Arctic sea routes between the Atlantic and Pacific oceans serve as new passages for international maritime transportation organizations that provide financial and time savings due to the shorter distance between the East Asia and Western Europe voyages [17]. Although the transit numbers are still few today, the number of operations has been rising [18]. The Northern Sea Route (NSR) will become an available course for open water ships, and the probability of transit will increase by approximately 94-98\% between 2040-2059 [19]. Moreover, a research regarding the transportation in the Arctic proves that the NSR could be a good alternative route for global logistics [20]. Additionally, two types of shipping activities are expected to grow in the Arctic region: (1) transit shipping, travel, and transfer of goods from one port to another; and (2) regional shipping to exploit natural resources. Once there are more open waters, the Arctic may witness a boost in traffic with the growth in the extraction of the natural reserves. For instance, there is already an increasing amount of oil and gas transport traffic in the Barents Sea, tourism traffic in Svalbard, and local fishing in Canada's northern waters [21,22]. The exploration of vast oil and gas resources will pave new opportunities in the Arctic for international operators to expand icebreaker fleets and invest in iceclass ships. On the other hand, a significant increase has been observed in large and small passenger ships, private yachts, fishing vessels, and research vessels [23,24]. For instance, the trends in visiting these remote areas by passenger ships to seek out unique ecosystems and species have been facilitated by tourists [25]. On the other hand, Antarctic resources are protected by the Antarctic Treaty (AT) signatory countries, which recognize tourism and fishing as the only profitable activities [26,27]. Additionally, AT consultative and observing countries enter the region in their vessels to conduct scientific studies in Antarctica. As the number of vessels increases because of the situation created by lower quantities of sea ice, numerous environmental and maritime safety issues have been developed [28]. Maritime activities are dangerous and pose a threat to sensitive polar ecosystems and vulnerable marine wildlife and habitats. Moreover, the polar environment's harshness presents significant risks such as floating ice, thick fog, and polar storms that may cause ice damage or stocking in the ice, running aground, and machinery malfunctions. Thus, the risks and hazards of extreme circumstances of the polar regions should be grasped to take advantage of commercial benefits [29]. Ice navigation research also highlights challenges that involve the interpretation of sea ice conditions, weather, ship classifications, icebreaker assistance, and crew experience [30]. An investigation of maritime accidents in the polar regions revealed that the accidents have mostly been related to sea ice, which are further categorized as ice floe hit, being trapped by ice, and ice jets [31]. On the other hand, navigational challenges and the risks for the ships operating in the polar regions are pointed out by authors as route selection problem, root cause analysis of Arctic marine accidents, and navigational risk assessment of Arctic navigation [32-34].

The existence of sea ice limits maritime operations at high latitudes in both hemispheres. Thus, it is essential to know the characteristics of sea ice and its formation, and monitoring and producing sea ice forecasts is crucial to support maritime operations [35]. The Polar Code (PC)'s efforts to mitigate the hazards and reduce risks to the environment elevate "seaworthiness" to a higher standard [36]. However, there is a single mandatory PC for both polar regions. Although the preamble of the PC notes the differences between the two areas, our study argues that some significant differences regarding the sea ice have not been evaluated in the content. The questions are, what are these differences and what are their interactions with PC. This study provides an overview of the differences of the Arctic and Antarctic sea ice conditions via remote sensing data analyses in the PC's scope. This study indicates the inadequacies of PC with some evidences of the impacts of the ice conditions for ice navigation for further studies. Consequently, this study declares the research gaps for further studies on the polar regions' maritime safety.

\section{Study Area}

\subsection{Sea Ice in Arctic and Antarctic}

The most apparent difference between the Northern Hemisphere and Southern Hemisphere is their geographical conditions [6,37-40]. The changes in SIE for each hemisphere are clarified in the figures below. Figure 1 (a) and (b) demonstrate an example of the maximum (max) and minimum (min) Arctic SIE based on the data from the National Snow and Ice Data Center (NSIDC).

NSIDC states that the SIE typically covers about 14 million sq $\mathrm{km}$ in winter and 5 million sq $\mathrm{km}$ in summer. The Arctic reaches the smallest SIE every September and grows to its maximum every March. The Arctic SIE has diminished by about three percent per decade since 1979 [41]. The Arctic sea ice thickness in summer has also declined dramatically from $3.64 \mathrm{~m}$ in 1980 to $1.89 \mathrm{~m}$ in 2008, exhibiting a total 
decrease of $48 \%$ in thickness [37]. However, as the ice sheets are more likely to crash into each other, a thick ridge ice occurs. The ridge ice does not generally melt during summer and continues to grow the following autumn. The Arctic SIE was 14.78 million sq $\mathrm{km}$ on March 20th, 2020 and 4.15 million sq km on September 18, 2019, which are $650,000 \mathrm{sq} \mathrm{km}$ and 2.10 million sq $\mathrm{km}$ below the 19812010 average min. extent, respectively [42]. Recent studies indicate that by 2030 , the September sea ice cover will shrink to $60 \%$, becoming less than $40 \%$ in the 2060 s and less than $10 \%$ by 2090 [11].

Most of the Antarctic is perennially coated by ice and snow. During winter, an average of 18 million sq $\mathrm{km}$ of sea ice exists, but only about 3 million sq $\mathrm{km}$ of sea ice remains in the summer. The Antarctic SIE reaches its min. every February and grows to its max. in September as shown in Figures 2 (a) and (b).
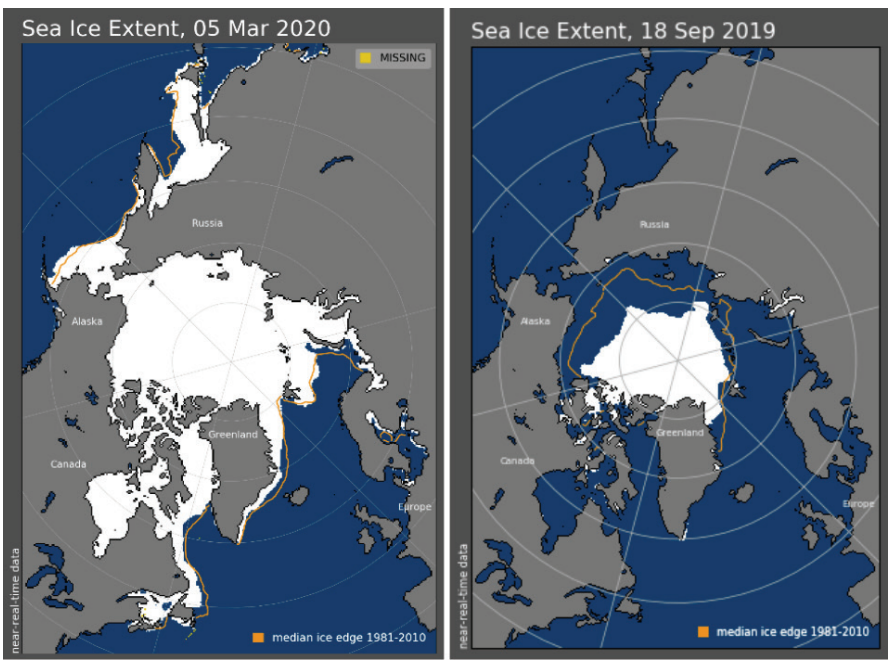

Figure 1. The Arctic SIE in (a) March 5 $5^{\text {th }}, 2020$ and (b) September $18^{\text {th }}, 2019$. The yellow line indicates the SIE in 1981-2010

Source: Data from NSIDC, 2019 [42]
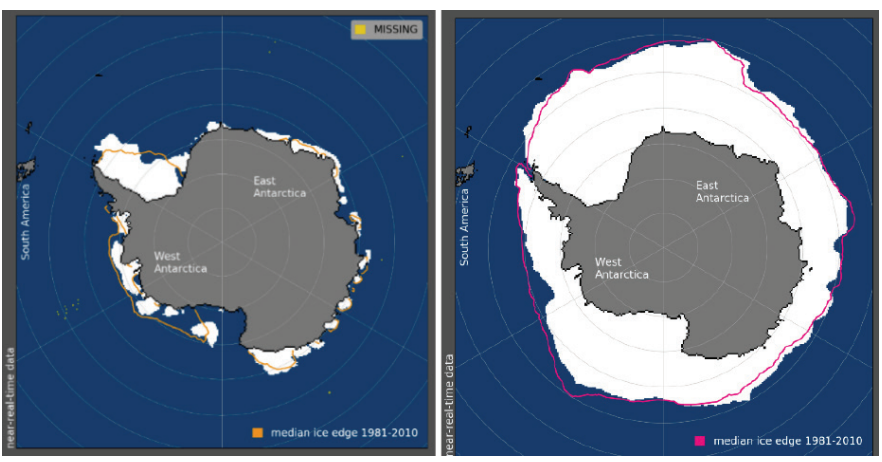

Figure 2. The Antarctic SIE in (a) February 20 ${ }^{\text {th }}, 2020$ (2.69 million sq km) and (b) September 2019 (18.244 million sq km). The yellow line indicates the SIE in 1981-2010

Source: Data from NSIDC, 2019 [42]
A nearly complete sea ice that forms during winters disperses during summers. The Antarctic annual sea ice max. extent was the second lowest according to the NSIDC satellite record in 2019. Further, the SIE diminished by 13.2\% in February 2019 compared to the averaged SIE for all the months of February from 1979 to 2009. The annual min. of the Antarctic SIE is 2.69 million sq km in February 2020 and 18.244 million sq km in September 2019, which are 0.404 million sq $\mathrm{km}$ and 0.234 million sq $\mathrm{km}$ below the 1981-2010 average min. extent, respectively [42].

Table 1 lists a variety of differences between the Southern and Northern hemisphere's sea ice parameters. Opposite geographical distributions are evident where the Arctic sea ice grows asymmetrically, whereas the Antarctic sea ice remains symmetric. Sea ice can currently exist at $38^{\circ} \mathrm{N}$ and $55^{\circ} \mathrm{S}$ in the in the Arctic and Antarctic regions, respectively. Owing to the difference in the sea ice evolution processes, the ice types differ. In the Antarctic, frazil ice is common and columnar surfaces are also found, though more rarely. In the Arctic, the topside of the ice comprises of frazil ice, while the downside is mainly congelation ice [39]. The Arctic ice melts at the air and ice interaction, whereas the Antarctic sea ice usually melts at the ocean and ice interaction. As a result, melt ponds are rarely observed in Antarctica, whereas melt ponds take a large part of the Arctic ice surface [43]. Thick and extensive ice shelves surround $75 \%$ of Antarctica's coastline; however, they are not typical for the Arctic [44]. In Antarctica, relatively large ice platelets are produced by the flowing, low salinity water underneath the ice shelves. These ice platelets can be present up to several meters in depth beneath a sea ice sheet. In contrast, platelet ice grows in pools in the Arctic region [45]. While Landfast ice is typically found at water depths in Antarctica, landfast ice in the Arctic comes in direct contact with the seafloor, because most of the shallow areas are sheltered by the ice shelves. Polynyas are divided into two types: (1) open-ocean polynyas and (2) coastal polynyas. Open-ocean polynyas

Table 1. Polar regions' sea ice differences

\begin{tabular}{|c|c|c|c|}
\hline \multicolumn{2}{|c|}{} & Arctic & Antarctic \\
\hline $\mathbf{1}$ & Latitude & $90^{\circ} \mathrm{N}-38^{\circ} \mathrm{N}$ & $55^{\circ} \mathrm{S}-75^{\circ} \mathrm{S}$ \\
\hline $\mathbf{2}$ & $\begin{array}{c}\text { Geometric } \\
\text { distribution }\end{array}$ & Asymmetric & Symmetric \\
\hline $\mathbf{3}$ & Type of ice & Mainly columnar & Mainly frazil \\
\hline $\mathbf{4}$ & Melting process & Air/ice interaction & Ocean/ice interaction \\
\hline $\mathbf{5}$ & Ice shelf & Not present & Present \\
\hline $\mathbf{6}$ & Platelet ice & Not present & Present \\
\hline $\mathbf{7}$ & Land fast ice & Over shallow water & Mainly over deep water \\
\hline $\mathbf{8}$ & Melt ponds & Significant & Insignificant \\
\hline $\mathbf{9}$ & Polynyas & Coastal & Open ocean \\
\hline
\end{tabular}


are estimated to occur due to the deep warm water that is mainly common in Antarctica, and Katabatic winds are believed to cause coastal polynyas that are typically found in the Arctic region [46].

\subsection{PC}

The International Maritime Organization (IMO) undertook work on a code for regulating the ship design, building, and operations in the early 1990s, and the guidelines for ships operating in Arctic ice-covered waters were accepted in 2002 [47]. Nevertheless, these guidelines applied only to the Arctic region and did not include the Antarctic region. Afterward, noteworthy arrangements were made by the IMO in 2009, amending them to cover the Antarctic waters [48]. Finally, the IMO changed the regulations from being mere guidelines to compulsory lawful requirements. This has been a long process for the PC, and it entered into legal force on January 1st, 2017 [49,50]. The PC is structured on the former IMO instruments and consists of two parts: Part I, introduction and safety measures and Part II, pollution prevention measures. Part II consists of five chapters that will not be evaluated in this study. Within the scope of PC, the sources of the hazards in the polar regions have been identified as ice, low temperature, periods of darkness and daylight, remoteness, and lack of accurate information and crew experience [50].

Consisting of 12 chapters, Part I of PC focuses on the safety of shipping in the polar waters and addresses a wide range of safety measures, including the need for ships to have a polar certificate and requirements according to the types of ships and ice conditions. Ships are categorized according to their design properties in different ice conditions. Every ship to which the PC applies shall have a Polar Ship Certificate (PSC) concerning the design and construction of the ships and equipment, crew and passenger clothing, ice removal, and fire safety. To support in the decision-making process, the Polar Water Operational Manual (PWOM) was developed to provide standards for vessels and crew, information about the ship's specific operational capabilities, limitations, and procedures to be followed in normal operations and in the event of incidents [50]. Other chapters of Part I include the ship structure, subdivision and stability, watertight and weathertight integrity, machinery installations, fire safety/ protection, life-saving appliances and arrangements, the safety of navigation, communication, voyage planning, and manning and training. Additionally, the polar operational limit assessment risk indexing system is a significant tool for assessing the ships' operational limitations and risks of navigation in ice. It is similar with the PSC and PWOM, but it is not a mandatory requirement. Its limitations are the human factor, the frame of application, and legal status
[51]. According to a PC research, shortcomings are stated that it does not exclude fishing and leisure vessels, it does not propose advanced training for all crew members, and the pollution risks are not adequately addressed. Additionally, it does not consider the crew's experience, and all Arctic aspects such as light ice conditions and ships without ice class are treated insufficiently [52].

\section{Methodology}

Sea ice observations have been carried out in the ships and coastal stations for more than 100 years. However, considering the remoteness of the Arctic and Antarctic regions, in situ measurements are not practical. For this reason, the satellite era, which gained momentum at the beginning of the 1960s, has become the most crucial observation method for the polar regions. Data from the satellites are utilized widely in research and in monitoring the SIE and other parameters $[35,53]$.

The evolution of remote sensing systems for satellites commenced with the launch of the Russian Cosmos-243 satellite in 1968. Later, The National Aeronautics and Space Administration (NASA) launched the electrically scanning microwave radiometer (ESMR), which supplied data from 1972 to 1977 . However, these satellites could not meet the technical requirements; therefore, development studies continued. With the development of new satellite systems, sea ice data has gained reliability. After the ESMR period, the scanning multichannel microwave radiometer (SMMR) was operated from 1978 to 1987. SMMR more correctly perceived the sea ice concentration extent with at least 15\% sea ice. The US's Defense Meteorological Satellite Program introduced passive microwave sensors, special sensor microwave imager (SSM/I), and particular sensor microwave imager and sounder instruments. The first long-term sea ice data was provided for scientists after the introduction of SSMR [54]. In 2003, NASA launched the Ice, Cloud, and land Elevation Satellite (ICESat) to track the sea ice thickness, ice sheet heights, and land cover. Further, the ICESat-2 launched in September 2018 provides a more comprehensive and precise ice thickness valuation, marking a significant development [55]. These instruments have provided the most extended and consistent time series of sea ice data, permitting research on the tendencies of the sea ice conditions in polar regions.

In 1993, NASA contracted NSIDC to serve as the Distributed Active Archive Center (DAAC), which provides a comprehensive data on sea ice, ice sheets, and ice shelves to support research. The NSIDC DAAC archive distribute cryospheric data from NASA and help researchers utilize the data products [54]. 


\section{Results}

\subsection{Arctic SIE}

Figure 3 (a) displays the average monthly SIE values in 1979-2019. The average monthly values from 1979 to 2009 are indicated by the thick blue curve, and the red line represents that of 2019, which remains below the average of 1979-2009 in all months. In the last decade, all values remained below the average and each year exceeds the recorded value of the previous year. In Figure $3(b-c)$, the average monthly SIE every March and September between 1979 to 2019 is indicated when the Arctic ocean begins to freeze and melt, respectively. The SIE in the Arctic region in March and September declines at a rate of $2.6 \%$ and $12.85 \%$ per decade, respectively. The linear trendline shows the steady decrease of the Arctic SIE for both months with

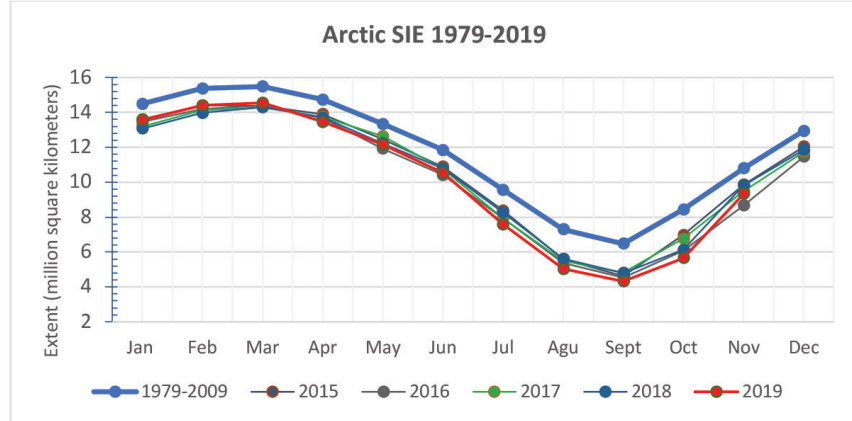

(a)

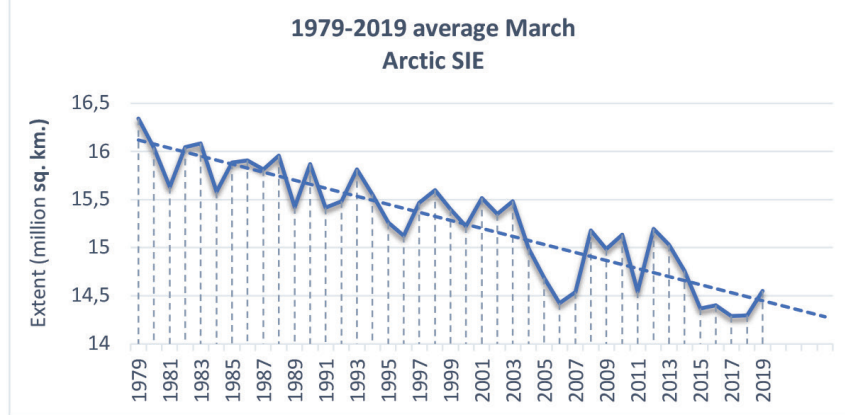

(b)

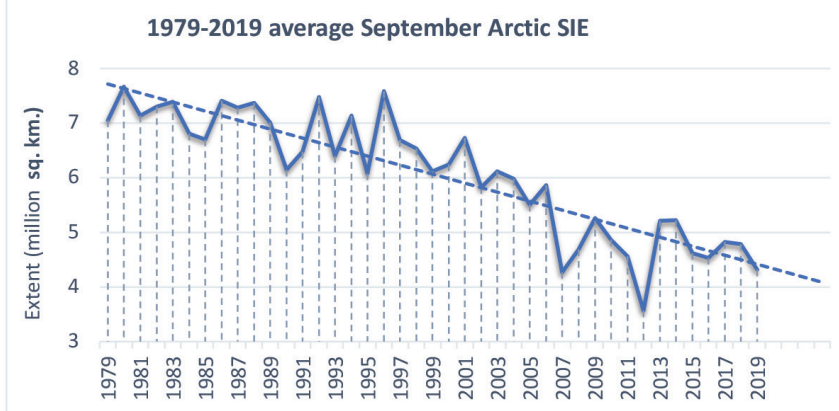

(c)

Figure 3. Arctic SIE in (a) in 1979-2019, (b) average in March 19792019, and (c) average in September 1979-2019

SIE: Sea ice extent the most significant decline experienced in September. As a result of this decreasing trend, the periods when the sea ice begins to freeze lengthen. September receives the most attention because it is the month with the least SIE.

\subsection{Antarctic SIE}

Figure 4 (a) displays the average monthly Antarctic SIE in 1979-2019. The thick blue curve indicates the average monthly SIE values from 1979 to 2015. Figure 4 (b-c) shows the average monthly Arctic SIE every February and September from 1979 to 2019. The SIEs in February and September 2017 are the lowest in the last decade. The Antarctic SIE values for February over the years are even lower than those in the Arctic in September. Further, the Antarctic SIE values for September are well above the Arctic max. SIE. The Antarctic monthly and annual SIE values (for

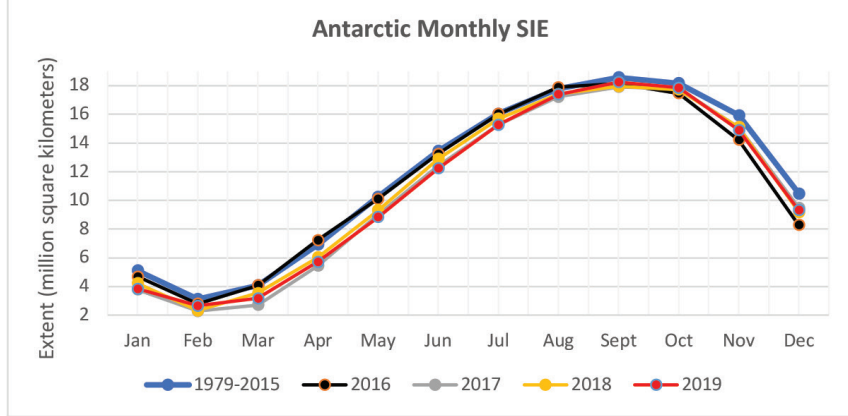

(a)

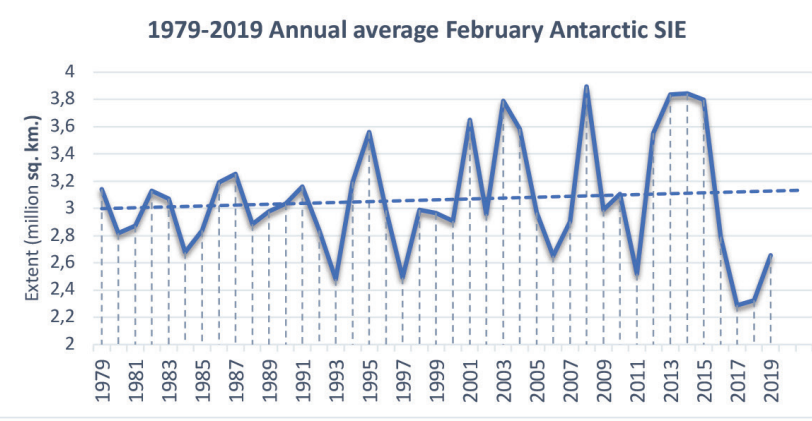

(b)

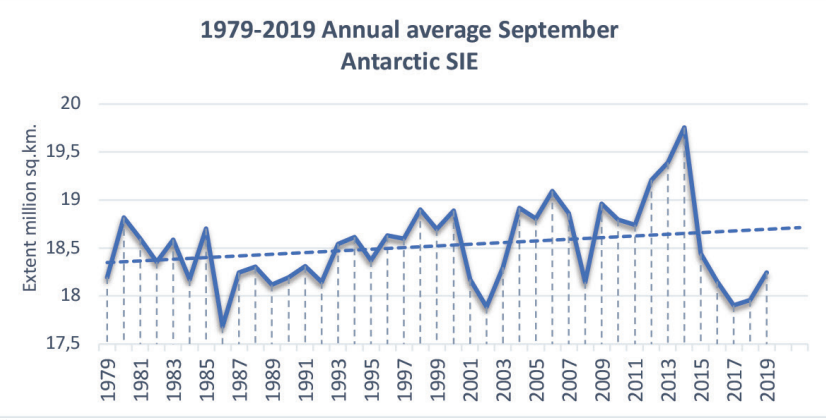

Figure 4. Antarctic SIE in (a) 1979-2019, (b) February 1979-2019, and (c) September 1979-2019

SIE: Sea ice extent 
the 41 years of the dataset, 1979-2019) indicate trends until 2014. Following that, a low record in three years is reached. The Antarctic min. monthly ice extent always occurs in February and is still less than five million sq $\mathrm{km}$.

As seen in Table 2, both polar regions reach their max. during winter and shrinks down to the min. during summer. The Arctic min. SIE in September 2012 and the max. SIE March 2017 extents have been the lowest recorded SIE by the satellite for 41 years. The lowest min. Arctic SIE was 3.56 million sq $\mathrm{km}$ in September 2012 and reached its second lowest recorded value in 2019. In 2019, the ice extent diminished by $33.23 \%$ and 6.1\% compared to the average in September and March (1979-2019), respectively. The lowest monthly average Antarctic SIE was 2.288 million sq km in February 2017, and the lowest recorded yearly average for the same was 10.75 million sq $\mathrm{km}$ in 2017. Snow thickness creates a big difference between both poles, reaching a considerable thickness in Antarctica as compared to the Arctic snow cover. Further ice thickening may be caused by snowfalls as well as melting and refreezing of snow. Sea ice thickness varies considerably within both regions. While the typical sea ice thickness of the Arctic is above two meters, the Antarctic sea ice is characteristically below the two-meter range. Multiyear ice, which has survived more than one melting season, is three meters thick or more and firmer than the one-year ice. A large part of the Arctic Ocean is composed of multiyear ice, where most of it occurs as pack ice. Resultantly, the strength of the ice is higher in the Arctic, which is vital for navigation. The average Arctic multiyear ice has significantly reduced from 1979 to 2019. The Antarctic mainly consists of seasonal ice that freezes and melts in a season and remains in a few coastal regions.

\section{Discussions}

The development of the PC and its importance and shortcomings for ice navigation are introduced in section 2.2. Although the PC states that the differences were taken into consideration in its efforts to adapt the Antarctic region, the changes and differences revealed in this study should be considered for the further development of PC.

The study related to navigational risks in ice-covered waters emphasizes the importance of environmental factors such as ice thickness, ice formation, weather conditions (e.g., wind, fog, visibility, and temperature), the drift of pack ice, floating ice floes, and ice restrictions, which affect the vessel's movement and etc. [32]. Because it is being surrounded by land, the sea ice stays in the Arctic water, while the opposite condition occurs in the Antarctic. Additionally, the SIE and volume are diminishing more rapidly in the Arctic than in the Antarctic. These are essential parameters regarding the ships' operational capabilities. Some crucial questions to be considered are where the ice is and where it is drifting, what kind of ice it is, how thick and strong it is, and whether there are icebergs. Within these questions' framework, different applications should be made for both regions depending on the sea ice conditions.

The area of the PC is also geographically limited. It can be extended to sea ice concentrations with a coverage of one-tenth or higher. The PC's Arctic boundary should be changed to cover the sea ice's edge of the 1979-2010 line, rather than the $60^{\circ} \mathrm{N}$ line [56]. As mentioned in previous sections, maritime activities in the Antarctic region involve passengers, fishing, research, and re-supply ships, whereas those in the Arctic include various types of vessels in operation. As an outcome of the implementation of the PC, patterns of activities are expected to differ within the Arctic and Antarctic regions. Additionally, while there has been

Table 2. Arctic and Antarctic SIE differences

\begin{tabular}{|c|c|c|c|}
\hline \multicolumn{2}{|c|}{} & Arctic & Antarctic \\
\hline $\mathbf{1}$ & Max./Min. SIE months & March/September & September/February \\
\hline $\mathbf{2}$ & Max. SIE & $16.342 \times 10^{6} \mathrm{~km}^{2}($ March 1979) & $2.288 \times 10^{6} \mathrm{~km}^{2}(\mathrm{February} 2017)$ \\
\hline $\mathbf{3}$ & Min. SIE & $3.566 \times 10^{6} \mathrm{~km}^{2}($ September 2012) & Small decrease \\
\hline $\mathbf{4}$ & The trends in SIE; 1979-2019 & Significant decrease & Thicker \\
\hline $\mathbf{5}$ & Snow thickness & Thinner & $0.5-0.6 \mathrm{~m}$ \\
\hline $\mathbf{6}$ & Mean thickness & $1976: 5 \mathrm{~m}$ & $<2 \mathrm{~m}$ \\
\hline $\mathbf{7}$ & Typical thickness & $>2 \mathrm{~m}$ & Low \\
\hline $\mathbf{8}$ & Strength of ice & High & Largely one-year ice \\
\hline $\mathbf{9}$ & The age of ice & Largely multiyear ice & $3.5 \times 10^{6} \mathrm{~km}{ }^{2}$ \\
\hline $\mathbf{1 0}$ & The average multiyear ice area & $\begin{array}{l}1979 \text { to } 1996 ; 5.531 \times 10^{6} \mathrm{~km}^{2}, \\
1997 \text { to } 2016 ; 4.226 \times 10^{6} \mathrm{~km}^{2}\end{array}$ \\
\hline
\end{tabular}


an increase in the Arctic maritime activities, no significant increase in the traffic density is observed in Antarctica in recent years. The number of unique ships entering the Arctic PC area in the month of September from 2013 to 2019 has increased by 25\% (1298 to 1628 ships), and the total distance sailed by all vessels increased by $75 \%$ [57]. Besides, many vessels that are currently operating in the polar regions are the non-parties to The International Convention for the Safety of Life at Sea (non-SOLAS), which means that the vessels are not compliant with PC and may present risks.

There are several definitions of sea ice for navigation. As mentioned in previous sections, $30 \%$ of Arctic sea ice is multiyear ice (3 $\mathrm{m}$ or thicker), while the Antarctic mainly has first-year ice $(0.3 \mathrm{~m}-2 \mathrm{~m}$ thick). First-year ice may damage the vessel's hull and multiyear ice impact may exceed the force of the vessel's strength. On the other hand, if the vessel's machinery power is limited, drifting ice can easily collapse and the vessel might beset in the ice. Moreover, the drift ice motion takes place differently even within each region [58,59]. There should be up-to-date ice information for masters sailing in the polar regions to make tactical navigation decisions.

On the other hand, the goal of PC Part I, Chapter 11, "Voyage Planning," is to ensure sufficient information for the safety of the ships, the crew, and the passengers and to protect the environment. One of the most critical issues in this chapter is that the master shall consider a route, taking into account the areas that are remote from search and rescue (SAR) capabilities. The remoteness, lack of infrastructure and assets, lack of accurate charting, and the harshness of the environment make the emergency response and SAR operations significantly more difficult in the Antarctic. Additionally, it is highlighted in the Council of Managers of National Antarctic Programs report (SAR Workshop IV SAR Coordination and Response in the Antarctic) that although there are significant differences between the polar regions, there would be best practices to learn from Arctic SAR agencies [60]. Moreover, multiple criteria such as regulations and restrictions, traffic congestion, charges, route length, sea depth, weather, and sea conditions are the critical factors for voyage planning, which differs in two regions [61]. For instance, the ice-strengthened passenger ship M/S Explorer was the first ship that sunk in the Antarctic waters following a collision with ice in 2007. According to the incident report, the primary cause was the ship captain's misjudgment of ice where they were countering. Even though he worked in the Baltic Sea, the Antarctic ice conditions have shown to be rather different from those in the Baltic $[62,63]$.
The human factor in the polar regions is crucial and experienced people are needed. The human element was the primary contributor to the total number of accidents (roughly 77\%) due to inattention, heavy weather, age, and lack of communication [24]. Seafarers are usually inadequately trained to deal with polar conditions $[30,64]$. PC Part I Chapter 12, "Manning and Training," aims to ensure adequately qualified, trained, and experienced personnel. There should be a curriculum that addresses the polar regions' differences for ice navigation in polar waters in basic and advanced level training.

\section{Conclusions}

This study analyzed the SIE changes in the Arctic and Antarctic regions based on the NSIDC datasets. After reviewing the 41-year satellite records, SIE's variations indicated a long-term trend of reduction from 1979 to 2019. Although some studies have demonstrated these lessening outcomes, our analysis takes a precise approach regarding the differences in the PC's scope. The differences in the Arctic and Antarctic sea ice characteristics were compared within some limitations. Because the results are obtained through remote sensing data analysis, they represent changes in ice conditions observed by satellites only. The differences observed according to the formation processes and features of sea ice that concern navigation have been introduced. As explained in the methodology chapter, SIE changes measured from the data obtained from various satellite and remote sensing systems were interpreted for both regions in our results. In the discussion section, some critical issues arising from the sea ice condition differences in ice navigation were pointed out. Our study confirms that the PC should be improved. For further studies, researchers should consider the density traffic of the vessels excluded in the PC. Considering the results of this study, maritime safety tools can be generated separately for the polar regions. PC Part II, Pollution prevention measures, should also be evaluated differently, which are the research gaps to be developed for the polar regions. Regardless, this study's investigation points to the need for future improvements of the mandatory PC for each polar region separately.

\section{Authorship Contributions}

Concept Design: M. Karahalil, B. Özsoy, Data Collection or Processing: M. Karahalil, B. Özsoy, Analysis or Interpretation: M. Karahalil, B. Özsoy, Literature Review: M. Karahalil, B. Özsoy, Writing, Reviewing and Editing: M. Karahalil, B. Özsoy.

Funding: The authors declared that this study received no financial support. 


\section{Acknowledgment}

This study was carried under the auspices of the Presidency of the Republic of Turkey, supported by the Ministry of Industry and Technology and coordinated by TUBITAK MRC Polar Research Institute.

\section{References}

[1] Z. Sun, and R. Beckman, "The Development of the Polar Code and Challenges to Its Implementation," In Global Commons and the Law of the Sea, vol. 5, Brill Nijhoff, 2018, pp. 303-325.

[2] T. Zieliński, M. Darecki, and J. M. Węsławski, (n.d.). CLIMATERELATED CHANGES IN THE ARCTIC ENVIRONMENT, EduCO2cean Magazine. http://magazine.educo2cean.org/wpcontent/uploads/sites/2/2018/03/9.-CLIMATE-RELATEDCHANGES-IN-THE-ARCTIC-ENVIRONMENT.pdf

[3] THE ANTARCTIC TREATY. (n.d.) https://www.ats.aq/e/ antarctictreaty.html.

[4] I. Simmonds, "Comparing and contrasting the behaviour of Arctic and Antarctic sea ice over the 35 year period 1979-2013," Annals of Glaciology, vol. 56, pp. 18-28, 2015.

[5] O. A. Anisimov, et al. 2007: Polar regions (Arctic and Antarctic). Climate Change 2007: Impacts, Adaptation and Vulnerability. Contribution of Working Group II to the Fourth Assessment Report of the Intergovernmental Panel on Climate Change, M.L. Parry, O.F. Canziani, J.P. Palutikof, P.J. van der Linden and C.E. Hanson, Eds., Cambridge University Press, Cambridge, 653-685.

[6] T. Maksym, S. E. Stammerjohn, S. Ackley, and R. Massom, “Antarctic sea ice-a polar opposite?" Oceanography, vol. 25, pp. 140-151, September 2012.

[7] R. K. Pachauri et al. Climate change 2014: synthesis report. Contribution of Working Groups I, II and III to the fifth assessment report of the Intergovernmental Panel on Climate Change [Core Writing Team, R.K. Pachauri and L.A. Meyer (eds.)]. IPCC, Geneva, Switzerland, pp 151, 2014.

[8] V. Masson-Delmotte, P. Zhai, H. O. Pörtner, D. Roberts, J. Skea, P. R. Shukla, et al. Global warming of $1.5^{\circ} \mathrm{C}$ An IPCC Special Report on the impacts of global warming of $1.5^{\circ} \mathrm{C}$ above pre-industrial levels and related global greenhouse gas emission pathways, in the context of strengthening the global response to the threat of climate change, sustainable development, and efforts to eradicate poverty, Summary for Policymakers Edited by Science Officer Science Assistant Graphics Officer, Working Group I Technical Support Unit. https://www.ipcc.ch/site/assets/uploads/ sites/2/2019/06/SR15_Full_Report_Low_Res.pdf

[9] Climate Change | United Nations. (n.d.). Retrieved February 6, 2020, from https://www.un.org/en/sections/issues-depth/ climate-change/

[10] R. Gerdes, and C. Koeberle, "Comparison of Arctic sea ice thickness variability in IPCC climate of the 20th century experiments and in ocean-sea ice hindcasts," Journal of Geophysical Research Atmospheres, vol. 112, April 2007.

[11] J. E. Overland, and M. Wang, "When will the summer Arctic be nearly sea ice free?" Geophysical Research Letters, vol. 40, pp. 2097-2101, March 2013.

[12] J. C. Stroeve, T. Markus, L. Boisvert, J. Miller, and A. Barrett, "Changes in Arctic melt season and implications for sea ice loss,"
Geophysical Research Letters, vol. 41, pp. 1216-1225, February 2014.

[13] D. Notz, and J. Stroeve, "The trajectory towards a seasonally icefree Arctic ocean." Current Climate Change Reports, vol. 4 pp. 407-416, September 2018.

[14] T. S. Rogers, J. E. Walsh, T. S. Rupp, L. W. Brigham, and M. Sfraga, "Future Arctic marine access: Analysis and evaluation of observations, models, and projections of sea ice." The Cryosphere Discussions, Publisher: European Geosciences Union vol. 7 pp. 321-332, February 2013.

[15] C. L. Parkinson, "A 40-y record reveals gradual Antarctic sea ice increases followed by decreases at rates far exceeding the rates seen in the Arctic," Inaugural Article, vol. 116, pp. 14414-14423, Jul 2019.

[16] M. Humpert, and A. Raspotnik, "The future of Arctic shipping along the transpolar sea route," August 2012.

[17] Arctic Shipping: Navigating the Risks and Opportunities, 2014. https://www.marsh.com/us/insights/research/arcticshipping-navigating-risks-opportunities.html

[18] L. C. Smith, and S. R. Stephenson, "New Trans-Arctic shipping routes navigable by midcentury." Proceedings of the National Academy of Sciences, vol. 110, pp. 1191-1195, March 2013.

[19] Issue 328. (2013). https://doi.org/10.1073/pnas.1214212

[20] B. Şahin, Y.E. Şenol, and Ş. E. Kartal, "Swot analysis of transportation in the arctic region," Published Abstract Title: CXXII. International Logistics and Supply Chain Congress, Paper Title Papers: Supply Chains of the Future, pp. 669-683, October 2014.

[21] 0. J. Borch, "Offshore service vessels in high arctic oil and gas field logistics operations: fleet configuration and the functional demands of cargo supply and emergency response vessels," 2018. http://hdl.handle.net/11250/2486368.

[22] N. A. Marchenko, O. J. Borch, S. V. Markov, and N. Andreassen, "Maritime Safety in The High North - Risk and Preparedness," The 26th Int. Ocean and Polar Eng. Conf. Rhodes, Greece [Online]. Available: https://onepetro.org/ISOPEIOPEC/proceedingsabstract/ISOPE16/All-ISOPE16/ISOPE-I-16-363/17796. [Accessed: 26 June 2016].

[23] J. C. Erazo, "The Maritime Commons: Digital Repository of the World Maritime University, Shipping in Antarctica: can safety and environmental protection be addressed considering the existing legal regimes?", World Maritime University, 2009. https://commons.wmu.se/cgi/viewcontent. cgi?article=1346\&context=all_dissertations

[24] A. Council, "Arctic marine shipping assessment," January 2009. https://pame.is/projects/arctic-marine-shipping/57-projects/ amsa/amsa-2009-report

[25] D. Palma et al. "Cruising the marginal ice zone: climate change and Arctic tourism," Polar Geography, vol. 42, pp. 215-235, August 2019. https://doi.org/10.1080/1088937X.2019.1648585

[26] Report on IAATO Operator Use of Antarctic Peninsula Landing Sites and ATCM Visitor Site Guidelines, 2018-19 Season, Information Paper submitted by IAATO. pp. 142-143, 2019.

[27] C. Erbe et al. "Managing the effects of noise from ship traffic, seismic surveying and construction on marine mammals in Antarctica," Frontiers in Marine Science, vol. 6, pp. 647, November 2019. https://doi.org/10.3389/fmars.2019.00647 
[28] ASOC. Antarctic Shipping, pp. 1-13, June 2008. http://www. asoc.org/storage/documents/Meetings/ATCM/XXXI/ASOC_IP_ on_shipping_050108_final.pdf

[29] S. Ghosh, and C. Rubly, "The emergence of Arctic shipping: issues, threats, costs, and risk-mitigating strategies of the Polar Code," Australian Journal of Maritime \& Ocean Affairs, vol. 7, pp. 171-182, October 2015. https://doi.org/10.1080/18366503.20 15.1093695

[30] S. Kum, and B. Şahin, "A survey on ice navigation research," Transactions of navigation, vol. 1, pp. 23-28, 2016.

[31] Marchenko, N. "Navigation in the Russian Arctic: Sea Ice Caused Difficulties and Accidents." Proceedings of the ASME 2013 32nd Int. Conf. on Ocean, Offshore and Arctic Eng. vol. 6: Polar and Arctic Sciences and Technology; Offshore Geotechnics; Petroleum Technology Symposium. Nantes, France. Jun 9-14, 2013. V006T07A011. ASME.

[32] B. Şahin, "Risk assessment and marine accident analysis in icecovered waters." Institute of Science and Technology, April 2015.

[33] S. Kum, and B. Sahin, "A root cause analysis for Arctic Marine accidents from 1993 to 2011," Safety Science, vol. 74, pp. 206220, April 2015.

[34] B. Sahin, S. Kum, "Route selection approach for vessels in ice covered waters," Marine Science and Technology Bulletin, vol. 3, pp. 1-4, December 2014.

[35] S. Sandven, O. M. Johannessen, and K. Kloster, "Sea ice monitoring by remote sensing," In book: Encyclopedia of Analytical Chemistry, vol. 6, pp. 241-283, September 2006.

[36] P. J. Cullen, "Polarworthiness: A new standard of seaworthiness in the polar context?" Polar Shipping and Arctic Development Symposium 42nd International Conference of the CMI, New York: May 2016.

[37] R. Kwok, and D. A. Rothrock, "Decline in Arctic sea ice thickness from submarine and ICESat records: 1958-2008," Geophysical Research Letters, vol. 36, August 2009. https://doi. org/10.1029/2009GL039035

[38] Sea ice ecosystems - MarineSpecies Introduced Traits Wiki. (n.d.). Retrieved May 21, 2020, from http://www.marinespecies. org/introduced/wiki/Sea_ice_ecosystems

[39] M. Spindler, "A comparison of Arctic and Antarctic sea ice and the effects of different properties on sea ice biota," In Geological history of the polar oceans: Arctic versus Antarctic, vol. 308, pp. 173-186, 1990.

[40] T. Maksym, "Arctic and Antarctic Sea Ice Change: Contrasts, Commonalities, and Causes," Annual Review of Marine Science, vol. 11, pp. 187-213, 2019. https://doi.org/10.1146/annurevmarine-010816-060610

[41] D. J. Cavalieri, and C. L. Parkinson, "Arctic sea ice variability and trends, 1979-2010," The Cryosphere, vol. 6, pp. 881-889, August 2012. https://doi.org/10.5194/tc-6-881-2012

[42] Arctic Sea Ice News and Analysis | Sea ice data updated daily with one-day lag. (n.d.). Retrieved November 5, 2019, from http://nsidc.org/arcticseaicenews/

[43] J. Zhang et al. "Melt pond conditions on declining Arctic Sea ice over 1979-2016: Model development, validation, and results," Journal of Geophysical Research: Oceans, vol. 123, pp. 7983-8003, October 2018.
[44] Ice shelves. Ice Shelf Collapse (n.d.). Retrieved May 21, 2020, from http://www.antarcticglaciers.org/glaciers-and-climate/ shrinking-ice-shelves/ice-shelves /

[45] G. Dieckmann, G. Rohardt, H. Hellmer, and J. Kipfstuhl, "The occurrence of ice platelets at $250 \mathrm{~m}$ depth near the Filchner Ice Shelf and its significance for sea ice biology," Deep Sea Research Part A. Oceanographic Research Papers, vol. 33, pp. 141-148, February 1986.

[46] Sea ice | ice formation | Britannica. (n.d.). Retrieved May 21, 2020, from https://www.britannica.com/science/seaice\# ref908438

[47] Ø. Jensen, "The IMO Guidelines for Ships Operating in Arctic Ice-covered Waters: From Voluntary to Mandatory Tool for Navigation Safety and Environmental Protection," FNI-Report 2/2007.

[48] The Developing International Maritime Organization Polar Code - Arctic Yearbook. (n.d.). Retrieved March 25, 2020, from https://arcticyearbook.com/arctic-yearbook/2014/2014commentaries/108-the-developing-international-maritimeorganization-polar-code

[49] Ø. Jensen, "The international code for ships operating in polar waters: finalization, adoption and law of the sea implications," Arctic Review on Law and Politics, vol. 7, pp. 6082, May 2016.

[50] Polar Code. (n.d.). Retrieved May 3, 2020, from http://www.imo. org/en/MediaCentre/HotTopics/polar/Pages/default.aspx

[51] L. Fedi, POLARIS in the Arctic, pp. 58-71, 2018.

[52] L. Fedi, O. Faury, and D. Gritsenko, "The impact of the Polar Code on risk mitigation in Arctic waters: a "toolbox" for underwriters?" Maritime Policy and Management, vol. 45, pp. 478-494, March 2018.

[53] B. Ozsoy-Cicek, S. F. Ackley, A. Worby, H. Xie, and J. Lieser, "Antarctic sea-ice extents and concentrations: comparison of satellite and ship measurements from International Polar Year cruises." Annals of Glaciology, vol. 52, pp. 318-326, 2011.

[54] 25 years servicing NASA's Earth Observing System data National Snow and Ice Data Center. (n.d.). Retrieved May 3, 2020, from https://nsidc.org/nsidc-monthly-highlights/2018/08/25years-servicing-nasa's-earth-observing-system-data

[55] ICESat-2 | National Snow and Ice Data Center. (n.d.). Retrieved May 3, 2020, from https://nsidc.org/data/ICESat-2

[56] M. Karahalil, B. Ozsoy, and O. Oktar, "Polar Code application areas in the Arctic." WMU Journal of Maritime Affairs, vol. 19, pp. 219-234, May 2020.

[57] PAME. (2020). THE INCREASE IN ARCTIC SHIPPING. Retrieved from https://storymaps.arcgis.com/ stories/592bfe70251741b48b0a9786b75ff5d0/print

[58] L. D. Talley, G. L. Pickard, W. J. Emery, and J. H. Swift, "Arctic Ocean and Nordic Seas," in Descriptive Physical Oceanography, $6^{\text {th }}$ ed., 2011, pp. 401-436. https://doi.org/10.1016/b978-0-75064552-2.10012-5

[59] Ice Drift - an overview / ScienceDirect Topics. (n.d.). Retrieved December 16, 2020, from https://www.sciencedirect.com/ topics/earth-and-planetary-sciences/ice-drift

[60] FINAL REPORT Antarctic Search and Rescue (SAR) Workshop IV Improving SAR Coordination and Response in the Antarctic 
Antarctic Search and Rescue (SAR) Workshop IV Improving SAR Coordination and Response in the Antarctic, pp. 15-16, May 2019.

[61] B. Şahin, "Route prioritization by using fuzzy analytic hierarchy process extended dijkstra algorithm." Journal of ETA Maritime Science, vol. 7, pp. 3-15, March 2019. https://doi.org/10.5505/ jems.2019.39306

[62] E. J. Stewart, and D. Draper, "The sinking of the MS Explorer: Implications for cruise tourism in Arctic Canada" Arctic, vol. 61, pp. 224-228, June 2008.
[63] Explorer - Final Report.PDF. (n.d.). http://www.photobits.com/ dl/Explorer\%20-\%20Final\%20Report.PDF

[64] M. Karahalil, and B. Özsoy, "Arctic shipping and human risk factors," The Journal of Ocean Technology, vol. 13, pp. 107-114, March 2018. 